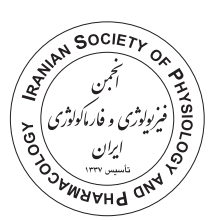

\title{
Effects of Boswellia serrata resin on central nervous system: a mini review
}

Narges Marefati $1^{1,2}$, Safoura Khamse ${ }^{3}$, Somaieh Mansouri ${ }^{4}$, Mahmoud Hosseini ${ }^{5,1}$, Akbar Anaeigoudari ${ }^{6 *}$ (DD

1. Applied Biomedical Research Center, Mashhad University of Medical Sciences, Mashhad, Iran

2. Department of Physiology and Medical Physics, Faculty of Medicine, Baqiyatallah University of Medical Sciences, Tehran, Iran

3. Iranian Research Center on Aging, University of Social Welfare and Rehabilitation Sciences, Tehran, Iran

4. Department of Anatomy, School of Medicine, North Khorasan University of Medical Sciences, Bojnurd, Iran

5. Psychiatry and Behavioral Sciences Research Center, Mashhad University of Medical Sciences, Mashhad, Iran

6. Department of Physiology, School of Medicine, Jiroft University of Medical Sciences, Jiroft, Iran

\begin{abstract}
Medicinal plants are used for different purposes in traditional medicine. Boswellia serrata (B. serrata) from Burseracea family has been widely used for human medical purposes. This plant known as frankincense or olibanum has a resin with therapeutic properties. The main constituent of this resin is boswellic acid that plays an important role in various fields. From past to present, many studies had been shown that olibanum and its main constituent, boswellic acid, have antiinflammatory, antioxidant, antitumor, anti-arthritic, antimicrobial and anti-carcinogenic effects. In addition, many findings about effects of $B$. serrata and its ingredients on central nervous system (CNS) are available. Therefore, the aim this study is to review in vivo and in vitro evidence attributed to this plant and its constituents on CNS. Databases including Web of Sciences, Scopus, PubMed and Google Scholar were explored for entries from the beginning of January 2000 until the end of November 2020. Findings reveal that $B$. serrata and its constituents have neuroprtotective effects and ameliorate learning and memory malfunction. These effects mainly are attributed to the antioxidant and anti-inflammatory properties of this plant.
\end{abstract}

\section{Keywords:}

Boswellia serrata

Frankincense

Olibanum

Central nervous system

\section{Introduction}

Boswellia serrata (B. serrata) is a tree with moderate height which flourishes in various regions of the world such as Middle East, North Africa and India (Kimmatkar et al., 2003, Hosseini-sharifabad and Esfandiari, 2015a). The extract of this plant is rich in gum, essential oils, resin, $\beta$-boswellic acid, phenolic compounds, terpenoids and polysaccharides (Yang et al., 2020). Elimination of free radical, reduction of pro-inflammatory cytokines, neutralization of pathogens and suppression of pain have been attributed to resin presented in extract of $B$. serrate (Siddiqui, 2011, Beghelli et al., 2017). Based on animal and human researches, $B$. serrata gum resin extract ameliorated the diseases affected from inflammation including osteoarthritis, asthma and rheumatoid arthritis (Abdel-Tawab et al., 2011). Decline of peritumoral brain edema followed by glioma by this herb has been also documented (Winking et al., 2000). Most pharmacological properties of $B$. serrata have been related to boswellic acids, 11-keto- $\beta$-boswellic acid (KBA) and

\footnotetext{
* Corresponding author: Akbar Anaeigoudari, Anaeia@jmu.ac.ir

Received 12 January 2021; Revised from 6 February 2021; Accepted 8 February 2021
}

Citation: Marefati N, Khamse S, Mansouri S, Hosseini M, Anaeigoudari A. Effects of Boswellia serrata resin on central nervous system: a mini review. Physiology and Pharmacology 2021; 25: 288-295. http://dx.doi.org/10.52547/phypha.25.4.5 
acetyl-11-keto- $\beta$-boswellic acid (AKBA), which can selectively inhibit 5-lipooxygenase (Kunnumakkara et al., 2009). These compounds have been reported to inhibit human leukocyte elastase and topoisomerases I and II $\alpha$ (Syrovets et al., 2005). Boswellic acids have been also shown to be able to diminish leukocyte-endothelial cell adhesive interaction and to reduce the number of rolling and adherent leukocytes when they were used orally in rats (Krieglstein et al., 2001). In addition, these acids induced apoptosis in the abnormal cells like glioblastoma cells, liver and colon cancer by increasing the level of death receptors and activating caspase-8 (Moussaieff and Mechoulam, 2009). Besides all these therapeutic properties attributed to $B$. serrata, in this review we reviewed the effects of this plant and its constituents on nervous system.

\section{Methods}

PubMed, Scopus and Google Scholar databases were used to collect scientific information from the beginning of January 2000 until the end of November 2020 in this review. The terms "Boswellia serrata", "boswellic acid", "olibanum", "frankincense", "central nervous system", "Learning and memory" were searched. Besides animal and human studies, in vitro searches were considered. Letters to Editor were excluded from this review.

\section{B. serrata resin constituents}

Frankincense is an oleo-gum resin extracted from $B$. serrata. It is constituted from $67 \%$ resin, $20-23 \%$ mucopolysaccharides and 5-9\% essential oil (Rijkers et al., 2006). The resin of B. serrata contains terpenoides including $\alpha$-thujene, $\alpha$-pinene, $\beta$-pinene cis-verbenol, trans-pinocarveol, myrcene, borneol, verbenone, p-cymene, limonene and boswellic acids (Syrovets et al., 2000, Kasali et al., 2002). Boswellic acids were known as main active ingredient among terpenoides (Siddiqui, 2011). Boswellic acids include KBA, AKBA and incensole acetate (Weber et al., 2006).

\section{Neuroprotective effects}

Hydro-alcoholic extract of $B$. serrata ( 3 and $6 \mathrm{pg} / \mathrm{ml}$ ) and its constituent AKBA ( 1 and $2.5 \mathrm{pg} / \mathrm{ml}$ ) protected PC12 neural cells against oxygen-glucose-serum deprivation-triggered cell injury. This neuroprotective effect was due to the alleviation of oxidative stress. In this study both the extract and AKBA could decrease
DNA oxidative damage, free radical concentration, lipid peroxidation (Sadeghnia et al., 2017). Aqueous and ethanolic extract of B. serrata $(125,250$ and $500 \mathrm{mg} /$ $\mathrm{kg})$ and AKBA $(50 \mathrm{mg} / \mathrm{kg}$ ) have been shown to lessen brain damage and to save the neurons of cerebral cortex against stroke in rats. This protective property was associated with reduction of lipid peroxidation, elevated level of glutathione and increased activity of superoxide dismutase in cerebral cortex (Forouzanfar et al., 2016). Intraperitoneal injection of KBA (10 or $50 \mathrm{mg} / \mathrm{kg}$ ) could lower glutamate concentration stimulated by kainic acid and prevent neuronal death in CA3 area of hippocampus in rats. It was proposed that suppression of glutamate release happened via inhibiting $\mathrm{N}$ - and $\mathrm{P} / \mathrm{Q}$-type $\mathrm{Ca} 2+$ channels from hippocampal synaptosomes and suppressing the activity of protein kinase $\mathrm{A}$ ( $\mathrm{Lu}$ et al., 2020). Intraperitoneal injection of AKBA $(5 \mathrm{mg} / \mathrm{kg})$ and dexamethasone $(1 \mathrm{mg} / \mathrm{kg})$ attenuated noxious impacts of lipopolysaccharide (LPS) on neuroinflammation in mice. This protective effect was due to decrement of inflammatory cytokines level as well as anti-amyloidogenic properties (Sayed et al., 2018). Acetyl-11-keto- $\beta$-boswellic acid $(20 \mathrm{mg} / \mathrm{kg})$ could also ameliorate neuronal damage in a rat model of middle cerebral artery occlusion. Treatment with AKBA was associated with enhancing the activity of nuclear factor-2-related factor $2 /$ hem oxygenase -1 pathway. This pathway reported to be as a main goal in brain protection against stroke (Ding et al., 2014). Assessment of neuroprotective properties of AKBA on neuronal damage caused by glutamate in neuron-like cells PC12 and N2a were examined. The results showed that $2.5-10 \mu \mathrm{M}$ of this compound rescued these cells from programmed cell death via down-regulating the expression ratio of $\mathrm{Bax} / \mathrm{Bcl} 2$ and inhibiting of caspase 3. These effects are also attributed to antioxidant properties of 3-Acetyl-11-keto- $\beta$-boswellic acid (Rajabian et al., 2020b). Researchers investigated the effects of B serrata gum resin on the morphology of pyramidal neurons in CA1 area of hippocampus in aged rats. Based on the results, administration of $100 \mathrm{mg} / \mathrm{kg}$ of B serrata gum resin for 8 weeks could increase the density of dendritic tree (Hosseini-sharifabad and Esfandiari, 2015b). The neuroprotective effects of $B$. serrata and its constituents were summarized in Table 1.

\section{Effects on learning and memory}

It has been documented that usage of 50 and $100 \mathrm{mg} /$ 
TABLE 1: Neuroprotective effects of $B$. serrata and its constituents

\begin{tabular}{|c|c|c|c|c|}
\hline Extract/Constituent & Dose & Study model & Effects & Ref. \\
\hline Hydro-alcoholic AKBA & $\begin{array}{c}3 \text { and } 6 \mathrm{pg} / \mathrm{ml} \\
5 \mathrm{mg} / \mathrm{kg}\end{array}$ & PC12 cells & $\begin{array}{l}\text { Decrease of DNA oxidative damage, } \\
\text { free radical concentration and lipid per- } \\
\text { oxidation }\end{array}$ & $\begin{array}{l}\text { Sadeghnia et } \\
\text { al., } 2017\end{array}$ \\
\hline $\begin{array}{l}\text { Aqueous and ethanolic } \\
\text { AKBA }\end{array}$ & $\begin{array}{l}125,250 \text { and } \\
500 \mathrm{mg} / \mathrm{kg} \\
50 \mathrm{mg} / \mathrm{kg}\end{array}$ & Rat & $\begin{array}{l}\text { Protection of neurons of cerebral cortex } \\
\text { against stroke through reducing lipid } \\
\text { peroxidation, elevating the level of glu- } \\
\text { tathione and increasing activity of su- } \\
\text { peroxide dismutase }\end{array}$ & $\begin{array}{l}\text { Forouzanfar et } \\
\text { al., } 2016\end{array}$ \\
\hline KBA & 10 or $50 \mathrm{mg} / \mathrm{kg}$ & Rat & $\begin{array}{l}\text { Prevention of neuronal death in CA3 } \\
\text { area of hippocampus through inhibiting } \\
\mathrm{N} \text { - and } \mathrm{P} / \mathrm{Q}-\text { type } \mathrm{Ca}^{2+} \text { channels and sup- } \\
\text { pressing glutamate release }\end{array}$ & Lu et al., 2020 \\
\hline AKBA & $5 \mathrm{mg} / \mathrm{kg}$ & Mice & $\begin{array}{l}\text { Attenuation of noxious impacts of lipo- } \\
\text { polysaccharide on neuro-inflammation }\end{array}$ & $\begin{array}{l}\text { Sayed et al., } \\
\quad 2018\end{array}$ \\
\hline AKBA & $20 \mathrm{mg} / \mathrm{kg}$ & Rat & $\begin{array}{l}\text { Prevention of neuronal damage in mid- } \\
\text { dle cerebral artery occlusion via enhanc- } \\
\text { ing the activity of nuclear factor-2-relat- } \\
\text { ed factor } 2 / \text { hem oxygenase }-1 \text { pathway }\end{array}$ & $\begin{array}{l}\text { Ding et al., } \\
2014\end{array}$ \\
\hline AKBA & $2.5-10 \mu \mathrm{M}$ & $\begin{array}{l}\text { Neuron-like } \\
\text { cells PC12 and } \\
\text { N2a }\end{array}$ & $\begin{array}{l}\text { Inhibition of programmed cell death via } \\
\text { down-regulating the expression ratio of } \\
\mathrm{Bax} / \mathrm{Bcl} 2 \text { and inhibiting of caspase } 3\end{array}$ & $\begin{array}{l}\text { Rajabian et al., } \\
2020 \text { b }\end{array}$ \\
\hline
\end{tabular}

$\mathrm{kg}$ of aqueous extract of frankincense fortified spatial memory retrieval dose-dependently in offspring rats. In this study treatment with extract heightened the level of mRNA expression of calcium/calmodulin kinase II (CaMKII) as a crucial player in memory formation in hippocampus tissue (Beheshti et al., 2018). The aqueous extract of $B$. serrata $(1 \mathrm{~g} / \mathrm{kg})$ was reported to increase dendritic processes of CA1 neurons in hippocampus. In this study $B$. serrata also augmented learning in pentylenetetrazol-kindled rats in passive avoidance task (Jalili et al., 2014). The useful effects of mixed extract of B. serrata $(200 \mathrm{mg} / \mathrm{kg})$ and Melissa officinalis $(400 \mathrm{mg} /$ $\mathrm{kg}$ ) on scopolamine-induced memory impairment have been also documented. The results of Morris Water Maze (MWM) test showed an enhancing effect in spatial memory in rats treated by extracts. This memory enhancing effect was attributed to antineuroinflammatory, antioxidant and anti-acetylcholine esterase properties these plants (Mahboubi et al., 2016). Oral administration of B. serrata extract ( 300 and $400 \mathrm{mg} / \mathrm{kg}$ ) could promote spatial learning ability in diabetic rats by streptozotocin. Improving effect of $B$. serrata was linked to suppress the activity of glycogen synthase kinase 3 beta (GSK-3ß), to alleviate oxidative stress status and to inhibit inflammatory responses in the brain of rats. Based on the results of this research the accumulation of amyloid plaques and neurofibrillary tangles in hippocampal tissue was also attenuated by extract (Gomaa et al.,
2019). Olibanum is a resin of $B$. serrata. Scientific evidences reveal that olibanum (100 and $500 \mathrm{mg} / \mathrm{kg}$ ) could restore hypothyroidism-triggered spatial memory deficits in rats. Based on the results of MWM test, traveled distance and delay to reach the hidden platform in rats treated with olibanum were lower than those of methimazole group (Hosseini et al., 2010). According the previous studies, boswellic acid (160mg/kg, IP) presented in gum resin of $B$. serrata restored cognitive dysfunction stimulated by trimethyltin in male Wistar rats in MWM test. These effects probable were mediated via reducing brain oxidative stress and inhibiting acetylcholine esterase enzyme (Ebrahimpour et al., 2017). In a study the effect of co-administration of AKBA $(5 \mathrm{mg} / \mathrm{kg})$ and celecoxib $(30 \mathrm{mg} / \mathrm{kg})$ as selective cyclooxygenase-2 inhibitor on LPS-agitated cognitive malfunction was checked in mice. In this work, the animals injected by AKBA and celecoxibe were more successful in performing behavioral tests including Y maze, radial maze and novel object recognition in comparison with mice treated by LPS. According the biochemical results of this study the memory repairmen followed by simultaneous use of AKBA and celecoxib likely resulted from diminishing the level of TNF- $\alpha$, glutamate and amyloid beta peptide in brain tissue of mice (Sayed et al., 2016). It has been documented that administration 5 and $10 \mathrm{mg} / \mathrm{kg}$ of AKBA 30min before LPS amplified retrieval memory in MWM and passive avoidance tasks by rats. Successful 
TABLE 2: Effects of B. serrate and its constituents on learning and memory

\begin{tabular}{|c|c|c|c|c|}
\hline Extract/Constituent & Dose & Study model & Effects & Ref. \\
\hline Aqueous extract & 50 and $100 \mathrm{mg} / \mathrm{kg}$ & Rat & $\begin{array}{l}\text { Improvement of spatial memory retrieval, } \\
\text { increase the level of mRNA expression of } \\
\text { CaMKII in hippocampus tissue }\end{array}$ & $\begin{array}{l}\text { Beheshti et } \\
\text { al., } 2018\end{array}$ \\
\hline Aqueous extract & $1 \mathrm{~g} / \mathrm{kg}$ & Rat & $\begin{array}{l}\text { Enhancement of dendritic processes of } \\
\text { CA1 neurons in hippocampus, augmenta- } \\
\text { tion of learning in PTZ-kindled in passive } \\
\text { avoidance task }\end{array}$ & $\begin{array}{l}\text { Jalili et al., } \\
\quad 2014\end{array}$ \\
\hline extract & $200 \mathrm{mg} / \mathrm{kg}$ & Rat & $\begin{array}{l}\text { Betterment of spatial memory in scopol- } \\
\text { amine-induced memory impairment via } \\
\text { reducing inflammatory responses, attenu- } \\
\text { ating oxidative stress and inhibiting acetyl- } \\
\text { choline esterase }\end{array}$ & $\begin{array}{l}\text { Mahboubi et } \\
\text { al., } 2016\end{array}$ \\
\hline $\begin{array}{l}\text { Extract (extracted with } \\
\text { petroleum ether) }\end{array}$ & $\begin{array}{l}300 \text { and } 400 \mathrm{mg} / \\
\mathrm{kg}\end{array}$ & Rat & $\begin{array}{l}\text { Promotion of spatial learning ability in } \\
\text { strepotozocin -induced diabetes through } \\
\text { suppressing the activity of GSK-3 } \beta \text {, allevi- } \\
\text { ating oxidative stress status and inhibitng } \\
\text { inflammatory responses and decreasing the } \\
\text { accumulation of amyloid plaques and neu- } \\
\text { rofibrillary tangles in hippocampus tissue. }\end{array}$ & $\begin{array}{l}\text { Gomaa et al., } \\
2019\end{array}$ \\
\hline Olibanum & $\begin{array}{l}100 \text { and } 500 \mathrm{mg} / \\
\mathrm{kg}\end{array}$ & Rat & $\begin{array}{l}\text { Repairmen of hypothyroidism-triggered } \\
\text { spatial memory deficits }\end{array}$ & $\begin{array}{l}\text { Hosseini et } \\
\text { al., } 2010\end{array}$ \\
\hline boswellic acid & $160 \mathrm{mg} / \mathrm{kg}$ & Rat & $\begin{array}{l}\text { Improvement of cognitive dysfunction } \\
\text { stimulated by trimethyltin via reducing } \\
\text { brain oxidative stress and inhibiting ace- } \\
\text { tylcholine esterase enzyme }\end{array}$ & $\begin{array}{l}\text { Ebrahimpour } \\
\text { et al., } 2017\end{array}$ \\
\hline AKBA & $5 \mathrm{mg} / \mathrm{kg}$ & Mice & $\begin{array}{l}\text { Reinforcement the performance of behav- } \\
\text { ioral tests including Y maze, radial maze } \\
\text { and novel object recognition through di- } \\
\text { minishing the level of TNF- } \alpha \text {, glutamate } \\
\text { and amyloid beta peptide in brain tissue }\end{array}$ & $\begin{array}{l}\text { Sayed et al., } \\
2016\end{array}$ \\
\hline AKBA & 5 and $10 \mathrm{mg} / \mathrm{kg}$ & Rat & $\begin{array}{l}\text { Amplification of retrieval memory in } \\
\text { MWM and passive avoidance tasks, eleva- } \\
\text { tion of IL-10, BDNF, superoxide oxide dis- } \\
\text { mutase and catalase and lowering TNF- } \alpha \text {, } \\
\text { IL- } 6 \text {, NO, glial GFAP and malondialde- } \\
\text { hyde in hippocampal tissue }\end{array}$ & $\begin{array}{l}\text { Marefati et } \\
\text { al., } 2020\end{array}$ \\
\hline AKBA & $5 \mathrm{mg} / \mathrm{kg}$ & Mice & $\begin{array}{l}\text { Improvement of cognitive disturbances } \\
\text { through reinforcing the signaling pathway } \\
\text { of Nrf } 2 / \text { Ho- } 1 \text { and intercepting inflamma- } \\
\text { tory pathways related to NF-kB }\end{array}$ & $\begin{array}{l}\text { Wei et al., } \\
2020\end{array}$ \\
\hline $\begin{array}{l}\text { Olibanum and ethanolic } \\
\text { extract }\end{array}$ & $\begin{array}{c}1 \mu \mathrm{m} \\
2 \mu \mathrm{g} / \mathrm{ml}\end{array}$ & B65 cell line & $\begin{array}{l}\text { Regulation of gene expression of CREB-1 } \\
\text { and CREB2 }\end{array}$ & $\begin{array}{l}\text { Jebelli et al., } \\
2019\end{array}$ \\
\hline
\end{tabular}

learning was accompanied with elevating IL-10, BDNF, superoxide oxide dismutase and catalase and lowering TNF- $\alpha$, IL-6, nitric oxide, glial fibrillary acidic protein and malondialdehyde (MDA) in hippocampal tissue of rats (Marefati et al., 2020). AKBA $(5 \mathrm{mg} / \mathrm{kg})$ has been also found to ameliorate cognitive disturbances through reinforcing the signaling pathway of $\mathrm{Nrf} 2 / \mathrm{Ho}-1$ and intercepting inflammatory pathways related to NF- $\mathrm{KB}$ in APPswe/PS1dE9 mice (Wei et al., 2020). CREB-1 and CREB2 are two main transcription factors which can promote memory-linked genes transcription and potent long term memory. It has been found that olibanum $(1 \mu \mathrm{m})$ and ethanolic extract of B serrata $(2 \mu \mathrm{g} / \mathrm{ml})$ reg- ulated gene expression of CREB-1 and CREB2 in B65 cell line (Jebelli et al., 2019). The effects of B. serrate and its constituents on learning and memory were exhibited in Table 2.

\section{Effects on neurodegenerative diseases}

Alzheimer's disease (AD) is well-known neurodegenerative disease in which memory is lost and person is unable to perform the daily activities (Brookmeyer et al., 2007). Beneficial effect of $B$. serrata and its constituents on $\mathrm{AD}$ was documented (Rajabian et al., 2020a). In a study the effect of aqueous extract of $B$. serrata (45 and $90 \mathrm{mg} / \mathrm{kg} /$ day) on $\mathrm{AD}$ induced by aluminum chloride 
TABLE 3: Effects of $B$. serrate and its constituents on neurodegenerative disorder

\begin{tabular}{|c|c|c|c|c|c|}
\hline Extract/Constituent & Dose & $\begin{array}{l}\text { Type of neurode- } \\
\text { generative disorder }\end{array}$ & Study model & Effects & Ref. \\
\hline aqueous & $\begin{array}{l}45 \text { and } 90 \\
\mathrm{mg} / \mathrm{kg}\end{array}$ & $\mathrm{AD}$ & Rat & $\begin{array}{l}\text { Improvement of behav- } \\
\text { ioral impairments caused } \\
\text { by } \mathrm{AlCl} 3 \text { in rotarod and } \\
\text { T-maze tests, increase of } \\
\text { acetylcholine and decrease } \\
\text { of acetycholinesterase in } \\
\text { the brain }\end{array}$ & $\begin{array}{l}\text { Yassin et al., } \\
2013\end{array}$ \\
\hline aqueous & $50 \mathrm{mg} / \mathrm{kg}$ & $\mathrm{AD}$ & Rat & $\begin{array}{l}\text { Attenuation of dementia } \\
\text { resulted from AD caused } \\
\text { by chronic intracerebro- } \\
\text { ventricular infusion of } \\
\text { streptozotocin }\end{array}$ & $\begin{array}{l}\text { Beheshti et } \\
\text { al., } 2016\end{array}$ \\
\hline Boswellic acid & $250 \mathrm{mg} / \mathrm{kg}$ & $\mathrm{AD}$ & Rat & $\begin{array}{l}\text { Decrease of glucose, tau } \\
\text { protein expression, MDA } \\
\text { and an increase superoxide } \\
\text { dismutase, catalase and glu- } \\
\text { tathione peroxidase in hip- } \\
\text { pocampus tissue }\end{array}$ & $\begin{array}{l}\text { Mohamed et } \\
\text { al., } 2021\end{array}$ \\
\hline Ethylalcoholic & $\begin{array}{c}125,250 \text { and } \\
500 \mathrm{mg} / \mathrm{kg}\end{array}$ & PD & Rat & $\begin{array}{l}\text { Mitigation of motor deficits } \\
\text { resulted from 6-OHDA in } \\
\text { rotational and elevated nar- } \\
\text { row beam tasks }\end{array}$ & $\begin{array}{l}\text { Doaee et al., } \\
2019\end{array}$ \\
\hline Boswellia resin & $10 \mu \mathrm{g} / \mathrm{ml}$ & PD & $\begin{array}{l}\text { SK-N-SH- } \\
\text { cell line }\end{array}$ & Protection against $\mathrm{MPP}^{+}$ & $\begin{array}{c}\text { Kazmi et al., } \\
2011\end{array}$ \\
\hline
\end{tabular}

was checked in rats. The results showed that high dose of extract improved behavioral impairments caused by aluminum chloride in rotarod and T-maze tests. In addition, both doses could increase the concentration of acetylcholine and decrease the level of acetycholinesterase in the brain of rats (Yassin et al., 2013).

Researchers also reported that aqueous extract of frankincense $(50 \mathrm{mg} / \mathrm{kg}$ for 42 days) time dependently restored dementia resulted from $\mathrm{AD}$ caused by chronic intracerebroventricular infusion of streptozotocin. According to the results of passive avoidance test, the latency time to enter the dark chamber was high and time spent in dark compartment also was low in rats treated by extract (Beheshti et al., 2016).

Boswellic acid has been also shown to have improving effects on $\mathrm{AD}$. It has been shown that boswellic acid $(250 \mathrm{mg} / \mathrm{kg}$ for 3 weeks) could ameliorate AD in an $A \beta$-induced rat model of this neurodegenerative disease. In this study the rats pretreated by boswellic acid had a decreased level of glucose, tau protein expression, MDA and an increased of antioxidant indexes such as superoxide dismutase, catalase and glutathione peroxidase in hippocampus tissue (Mohamed et al., 2021).

Parkinson's disease (PD) is a neurodegenerative disease accompanied with reduction or lack of dopamine in the brain and was characterized by muscle stiffness, bradykinesia and resting tremor (Rocha et al., 2015). The results of studies exhibit that $B$. serrata and its ingredients can debilitate PD symptoms (Rajabian et al., 2020a). Ethylalcoholic extract of B. serrata (125, 250 and $500 \mathrm{mg} / \mathrm{kg}$ ) has been reported to mitigate motor deficits in rotational and elevated narrow beam tasks in a 6-hydroxydopamine triggered rat model of PD. This protective effect on nigrostriatal dopaminergic neurons has been linked to anti-inflammmatory and antioxidant properties of B. serrata extract (Doaee et al., 2019).

In an in vitro study the effect of boswellia resin on neuronal death of SK-N-SH- cell line exposed by 1-methyl-4-phenylpyridinium (MPP+) was investigated. Based on results of this study $10 \mu \mathrm{g} / \mathrm{ml}$ of boswellia resin could protect this human dopaminergic cells against MPP+ (Kazmi et al., 2011). The effects of B. serrate and its constituents on neurodegenerative disorder were presented in Table 3.

\section{Anti-anxiety and anti-depressant effects}

Anxiety disorders are psychiatric disorders which are known by restlessness, presentiment and fear. It has been understood that 50 and $200 \mathrm{mg} / \mathrm{kg}$ of $B$. serrata could ameliorate anxiety behaviors in Swiss albino mice in light and dark arena and elevated plus maze tests. (Adake et al., 2015). In a clinical trial oral 
administration of B. serrata reduced the intensity and frequency of headaches in patients with chronic cluster headaches (Lampl et al., 2012). Incensole acetate as a major component of boswellia resin has been reported to have the anti-depressive and anxiolytic effects (Moussaieff and Mechoulam, 2009). In addition, it has been found that incensole acetate induced anti-anxiety and anti-depressant effects in behavioral mice models (Moussaieff et al., 2008).

\section{Conclusion}

Based on the results of this literature review, $B$. serrata and its constituents especially boswellic acid exert protective effect on central nervous system and improve learning and memory impairments. Scientific evidences reveal that neuroprotective effects of this medicinal plant mainly are attributed to its antioxidant and antiinflammatory properties. In addition, it was understood that $B$. serrata reinforces learning and memory via increasing acetylcholine and decreasing the level of acetycholinesterase in brain.

\section{Conflict of interest}

Not declared

\section{References}

Abdel-tawab M, Werz O, Schubert-zsilavecz M. Boswellia serrata: an overall assessment of in vitro, preclinical, pharmacokinetic and clinical data. Clin Pharmacokinet 2011; 50: 349-69. https://doi.org/10.2165/11586800-00000000000000

Adake P, Petimani MS, Jayaraj M, Rao S. Preclinical evaluation of Boswellia serrata for anxiolytic activity. Int J Basic Clin 2015; 4: 551-5. https://doi.org/10.18203/23192003.ijbcp20150038

Beghelli D, Isani G, Roncada P, Andreani G, Bistoni O, et al. Antioxidant and ex vivo immune system regulatory properties of Boswellia serrata extracts. Oxid Med Cell Longev 2017. https://doi.org/10.1155/2017/7468064

Beheshti S, Aghaie R. Therapeutic effect of frankincense in a rat model of Alzheimer's disease. Avicenna J Phytomed 2016; 4: 468.

Beheshti S, Skakakomi AG, Ghaedi K, Dehestani H. Frankincense upregulates the hippocampal calcium/calmodulin kinase II- $\alpha$ during development of the rat brain and improves memory performance. Int J Dev Neurosci 2018; 69: 44-8. https://doi.org/10.1016/j.ijdevneu.2018.06.011
Brookmeyer R, Johnson E, Ziegler-graham K, Arrighi HM. Forecasting the global burden of Alzheimer's disease. Alzheimers Dement 2007; 3: 186-91. https://doi.org/10.1016/j. jalz.2007.04.381

Ding Y, Chen M, Wang M, Wang M, Zhang T, Park J, et al. Neuroprotection by acetyl-11-keto- $\beta$-boswellic acid, in ischemic brain injury involves the $\mathrm{Nrf} 2 / \mathrm{HO}-1$ defense pathway. Sci Rep 2014; 4: 1-9. https://doi.org/10.1038/ srep07002

Doaee P, Rajaei Z, Roghani M, Alaei H, Kamalinejad M. Effects of Boswellia serrata resin extract on motor dysfunction and brain oxidative stress in an experimental model of Parkinson's disease. Avicenna J Phytomed 2019; 3: 281 .

Ebrahimpour S, Fazeli M, Mehri S, Taherianfard M, Hosseinzadeh H. Boswellic acid improves cognitive function in a rat model through its antioxidant activity: neuroprotective effect ofBoswellic acid. J pharmacopuncture 2017; 10. https://doi.org/10.3831/KPI.2017.20.001

Forouzanfar F, Hosseinzadeh H, Ebrahimzadeh Bideskan A, Sadeghnia HR. Aqueous and ethanolic extracts of Boswellia serrata protect against focal cerebral ischemia and reperfusion injury in rats. Phytother Res 2016; 30: 1954-67. https://doi.org/10.1002/ptr.5701

Gomaa AA, Makboul RM, Al-Mokhtar MA, Nicola MA. Polyphenol-rich Boswellia serrata gum prevents cognitive impairment and insulin resistance of diabetic rats through inhibition of GSK3beta activity, oxidative stress and proinflammatory cytokines. Biomed Pharmacother 2019; 109: 281-92. https://doi.org/10.1016/j.biopha.2018.10.056

Hosseini-Sharifabad M, Esfandiari E. Effect of Boswellia serrata gum resin on the morphology of hippocampal CA1 pyramidal cells in aged rat. Anat Sci Int 2015a; 90: 47-53. https://doi.org/10.1007/s12565-014-0228-Z

Hosseini-Sharifabad M, Esfandiari E. Effect of Boswellia serrata gum resin on the morphology of hippocampal CA1 pyramidal cells in aged rat. Anat Sci Int 2015b; 90: 47-53. https://doi.org/10.1007/s12565-014-0228-Z

Hosseini M, Hadjzadeh MA, Derakhshan M, Havakhah S, Rassouli FB, Rakhshandeh H, et al. The beneficial effects of olibanum on memory deficit induced by hypothyroidism in adult rats tested in morris water maze. Arch Pharm Res 2010; 33: 463-8. https://doi.org/10.1007/s12272-010$0317-\mathrm{z}$

Jalili C, Salahshoor M, Pourmotabbed A, Moradi S, Roshankhah SH, Darehdori AS, et al. The effects of aqueous extract of Boswellia Serrata on hippocampal region CA1 
and learning deficit in kindled rats. Res Pharm Sci 2014; 9: 351.

Jebelli A, Khalaj-Kondori M, Bonyadi M, Feizi MA, RahmatiYamchi M. Beta-boswellic acid and ethanolic extract of olibanum regulating the expression levels of CREB-1 and CREB-2 genes. Iran J Pharm Res 2019; 18: 877.

Kasali AA, Adio AM, Oyedeji AO, Eshilokun AO, Adefenwa M. Volatile constituents of Boswellia serrata Roxb. (Burseraceae) bark. Flavour Fragr J 2002; 17: 462-4. https:// doi.org/10.1002/ffj.1124

Kazmi S, Kafami L, Ebrahimi A, Jameie B, Joghataiee MT. The effects of boswellia resin extract on dopaminergic cell line, SK-N-SH, against MPP+-induced neurotoxicity. Basi Clin Neurosci 2011; 3: 16-21.

Kimmatkar N, Thawani V, Hingorani L, Khiyani R. Efficacy and tolerability of Boswellia serrata extract in treatment of osteoarthritis of knee-a randomized double blind placebo controlled trial. Phytomedicine 2003; 10: 3-7. https://doi. org/10.1078/094471103321648593

Krieglstein CF, Anthoni C, Rijcken EJ, Laukötter M, Spiegel HU, Boden SE, et al. Acetyl-11-keto- $\beta$-boswellic acid, a constituent of a herbal medicie from Boswellia serrata resin, attenuates experimental ileitis. Int J Colorectal Dis 2001; 16: 88-95. https://doi.org/10.1007/s003840100292

Kunnumakkara AB, Nair AS, Sung B, Pandey MK, Aggarwal BB. Boswellic acid blocks signal transducers and activators of transcription 3 signaling, proliferation, and survival of multiple myeloma via the protein tyrosine phosphatase SHP-1. Mol Cancer Res 2009; 7: 118-28. https://doi. org/10.1158/1541-7786.MCR-08-0154

Lampl C, Haider B, Schweiger C. Long-term efficacy of Boswellia serrata in four patients with chronic cluster headache. Cephalalgia 2012; 32: 719-22. https://oi. org/10.1177/0333102412451357

Lu CW, Lin TY, Wang SJ. 11-Keto-beta-Boswellic acid attenuates glutamate release and kainic acid-induced excitotoxicity in the rat hippocampus. Planta Med 2020; 86: 434-41. https://doi.org/10.1055/a-1107-9337

Mahboubi M, Taghizadeh M, Talaei SA, Firozeh SM, Rashidi AA, Tamtaji OR. Combined administration of Melissa officinalis and Boswellia serrata extracts in an animal model of memory. Iran J Psychiatry Behav Sci 2016; 10. https://doi.org/10.17795/ijpbs-681

Marefati N, Beheshti F, Memarpour S, Bayat R, Shafei MN, Sadeghnia HR, et al. The effects of acetyl-11-keto- $\beta$ boswellic acid on brain cytokines and memory impairment induced by lipopolysaccharide in rats. Cytokine 2020; 131:
155107. https://doi.org/10.1016/j.cyto.2020.155107

Mohamed TM, Youssef MA, Bakry AA, El-Keiy MM. Alzheimer's disease improved through the activity of mitochondrial chain complexes and their gene expression in rats by boswellic acid. Metab Brain Dis 2021; 36: 25564. https://doi.org/10.1007/s11011-020-00639-7

Moussaieff A, Mechoulam R. Boswellia resin: from religious ceremonies to medical uses; a review of in-vitro, in-vivo and clinical trials. J Pharm Pharmacol 2009; 61: 1281-93. https://doi.org/10.1211/jpp/61.10.0003

Moussaieff A, Rimmerman N, Bregman T, Straiker A, Felder CC, Shoham S, et al. Incensole acetate, an incense component, elicits psychoactivity by activating TRPV3 channels in the brain. FASEB J 2008; 22: 3024-34. https:// doi.org/10.1096/fj.07-101865

Rajabian A, Sadeghnia H, Fanoudi S, Hosseini A. Genus Boswellia as a new candidate for neurodegenerative disorders. Iran J Basic Med Sci 2020a; 23: 277.

Rajabian A, Sadeghnia HR, Hosseini A, Mousavi SH, Boroushaki MT. 3-Acetyl-11-keto- $\beta$-boswellic acid attenuated oxidative glutamate toxicity in neuron-like cell lines by apoptosis inhibition. J Cell Biochem 2020b; 121: 177889. https://doi.org/10.1002/jcb.29413

Rijkers T, Ogbazghi W, Wessel M, Bongers F. The effect of tapping for frankincense on sexual reproduction in Boswellia papyrifera. J Appl Ecol 2006; 43: 1188-95. https://doi.org/10.1111/j.1365-2664.2006.01215.x

Rocha NP, De Miranda AS, Teixeira AL. Insights into neuroinflammation in Parkinson's disease: from biomarkers to anti-inflammatory based therapies. Biomed Res Int 2015. https://doi.org/10.1155/2015/628192

Sadeghnia HR, Arjmand F, Ghorbani A. Neuroprotective effect of boswellia serrata and its active constituent acetyl 11-keto-beta-boswellic acid against oxygen-glucose-serum deprivation-induced cell injury. Acta Pol Pharm 2017; 74: 911-20.

Sayed AS, El Sayed NS. Co-administration of 3-acetyl-11-keto-beta-boswellic acid potentiates the protective effect of celecoxib in lipopolysaccharide-induced cognitive impairment in mice: possible implication of anti-inflammatory and antiglutamatergic pathways. J Mol Neurosci 2016; 59: 58-67. https://doi.org/10.1007/s12031-016-0734-7

Sayed AS, Gomaa IE, Bader M, El Sayed NS. Role of 3-acetyl-11-keto-beta-boswellic acid in counteracting LPS-induced neuroinflammation via modulation of miRNA-155. Mol Neurobiol 2018; 55: 5798-808. https://doi.org/10.1007/ s12035-017-0801-2 
Siddiqui MZ. Boswellia serrata, a potential anti-inflammatory agent: an overview. Indian J Pharm Sci 2011; 73: 255.

Syrovets T, Büchele B, Gedig E, Slupsky JR, Simmet T. Acetyl-boswellic acids are novel catalytic inhibitors of human topoisomerases I and II $\alpha$. Mol Pharmacol 2000; 58: 71-81. https://doi.org/10.1124/mol.58.1.71

Syrovets T, Büchele B, Krauss C, Laumonnier Y, Simmet T. Acetyl-boswellic acids inhibit lipopolysaccharide-mediated TNF- $\alpha$ induction in monocytes by direct interaction with IкB kinases. J Immunol 2005; 174: 498-506. https://doi. org/10.4049/jimmunol.174.1.498

Weber CC, Reising K, Müller WE, Schubert-Zsilavecz M, Abdel-Tawab M. Modulation of Pgp function by boswellic acids. Planta Med 2006; 72: 507. https://doi. org/10.1055/s-2006-931536

Wei C, Fan J, Sun X, Yao J, Guo Y, Zhou B, Shang Y. Acetyl- 11-keto- $\beta$-boswellic acid ameliorates cognitive deficits and reduces amyloid- $\beta$ levels in APPswe/PS1dE9 mice through antioxidant and anti-inflammatory pathways. Free Radic Biol Med 2020; 150: 96-108. https://doi.org/10.1016/j. freeradbiomed.2020.02.022

Winking M, Sarikaya S, Rahmanian A, Jödicke A, Böker DK. Boswellic acids inhibit glioma growth: a new treatment option? J Neurooncol 2000; 46: 97-103. https://doi. org/10.1023/A:1006387010528

Yang F, Cho WY, Lee N, Kim DH, Lee J, Lee HJ, et al. Effects of boswellia serrata and whey protein powders on physicochemical properties of pork patties. Foods 2020; 9 : 334. https://doi.org/10.3390/foods9030334

Yassin N, El-Shenawy S, Mahdy KA, Gouda N, Marrie A, Farrag A, Ibrahim BM. Effect of boswellia serrata on Alzheimer's disease induced in rats. J Arab Soc Med Res 2013; 8: 1. 